\title{
Use of passive safety supporting structures
}

\author{
Jarosław Michałek ${ }^{*}$ \\ Wroclaw University of Science and Technology, Faculty of Civil Engineering, \\ Wybrzeże Wyspiańskiego 27, 50-370 Wrocław, Poland
}

\begin{abstract}
Road safety issues have been raised for many years in subsequent national and EU documents. An example of a Polish document is the National Road Safety Program for 2013-2020 [1]. The priorities and measures adopted in the document [1] relate mainly to the environment and road furnishings making up the so-called passive road safety. In accordance with PN-EN 12767: 2008 [2], road lighting columns, as well as supporting structures for vertical road marking and traffic safety devices should be constructed in such a way that they do not pose a threat to road users in case of unforeseen situations ending up in a collision. Three categories of passive safety of support structures depending on the level of energy absorption during vehicle impact can be distinguished: high energy absorbing (HE), low energy absorbing (LE) and non-energy absorbing (NE) energy. The article presents an overview of solutions of several countries (USA, Norway, Sweden, Finland, Great Britain, Slovakia and Poland) in the use of support structures that minimize the impact of a collision. Particular attention was paid to the fact that due to the potential risk of secondary injuries sustained by other road users (pedestrians and cyclists) in relation to a specific installation site and designated speed limit, constructions in the $\mathrm{HE}$ or NE absorption class or even Class 0 constructions should be used.
\end{abstract}

\section{Introduction}

National Road Safety Program for 2013-2020 [1] is a Polish document adopted by the National Road Safety Council on June 20, 2013 (Resolution No. 5/2013), and is based on five pillars: safe person, safe roads, safe speed, safe vehicle as well as rescue and postaccident care.

Particular pillars priorities and measures adopted in the document [1] are as follows:

- safe person - among others popularizing and implementation of road protection measures for road users, in particular pedestrians and cyclists;

- safe roads - among others road modernization resulting from the needs of road safety (e.g. removing road infrastructure errors resulting in sections with the highest risk of fatalities, concept development and practical implementation of the so-called 'forgiving roads' equipped with passive safety measures and without dangerous side obstacles;

\footnotetext{
* Corresponding author: jaroslaw.michalek@pwr.edu.pl
} 
- safe speed - among others drawing up and popularising guidelines, rules and good practices of road design in terms of speed.

The above-mentioned priorities and measures adopted in the document [1] are mainly related to the environment and road furnishing constituting the so-called passive road safety. In road infrastructure, passive road safety is impacted by various types of devices or furnishings that reduce the likelihood of an accident or mitigate its consequences. These may be traffic lights, energy-absorbing road barriers, traffic signs and streetlights which during the collision, through appropriate shaping of the structure, absorb part of the kinetic energy from the vehicle during the impact phase.

\section{Passive safety of support structures}

In accordance with the PN-EN 12767:2008 [2], road lighting columns, as well as support structures for vertical road marking and traffic safety devices should be constructed in such a way that they do not pose a threat to road users in case of unforeseen emergency situations ending up in a collision.

The standard [2] distinguishes three categories of passive safety of support structures depending on the level of energy absorbed by them during the vehicle impact:

- high impact energy absorbing structure (HE),

- low impact energy absorbing structure (LE),

- impact energy non-absorbing structures (NE).

Also, class 0 constructions are mentioned, for which there are no requirements and no tests are required.

For each of the three categories of support impact energy absorbing structures in various ways the at speeds of 50,70 and $100 \mathrm{~km} / \mathrm{h}$ (Table 1), four safety levels of vehicle users were defined, and the degree of impact effects was determined, which is marked by the Acceleration Severity Index (ASI) and theoretical head velocity during the THIV (Theoretical Head Impact Velocity) collision, Table 2. The risk levels of vehicle users 1, 2 and 3 are assigned to supporting structures that increase occupant safety by reducing the effects of an impact. Level 4 includes very safe supporting constructions. The value of ASI is considered to be the severity of the driver's and passengers' accident in a vehicle hitting an obstacle. The theoretical velocity of the head on impact (THIV) is the speed expressed in $\mathrm{km} / \mathrm{h}$, at which the hypothetical 'mass point' of a passenger (head), being able to move freely in the vehicle, hits the surface inside the vehicle, assuming that the head remains in contact with this surface during the rest of the collision period (hence it is subjected to the same acceleration as the vehicle). More requirements for passive secure supporting structures are given in [3].

Table 1. Energy absorption categories [2].

\begin{tabular}{|c|c|c|c|}
\hline \multirow{2}{*}{$\begin{array}{c}\text { Category of } \\
\text { energy } \\
\text { absorption by } \\
\text { structure }\end{array}$} & 50 & 70 & 100 \\
\cline { 2 - 4 } & \multicolumn{3}{|c|}{ Velocity on impact $\mathrm{v}_{\mathrm{i}}, \mathrm{km} / \mathrm{h}$} \\
\hline $\mathrm{HE}$ & $\mathrm{v}_{\mathrm{e}}=0$ & $0 \leq \mathrm{v}_{\mathrm{e}} \leq 5$ & $0 \leq \mathrm{v}_{\mathrm{e}} \leq 50$ \\
\hline $\mathrm{LE}$ & $0 \leq \mathrm{v}_{\mathrm{e}} \leq 5$ & $5 \leq \mathrm{v}_{\mathrm{e}} \leq 30$ & $50 \leq \mathrm{v}_{\mathrm{e}} \leq 70$ \\
\hline $\mathrm{NE}$ & $0 \leq \mathrm{v}_{\mathrm{e}} \leq 50$ & $30 \leq \mathrm{v}_{\mathrm{e}} \leq 70$ & $70 \leq \mathrm{v}_{\mathrm{e}} \leq 100$ \\
\hline
\end{tabular}


High energy-absorbing support structures (HE) stop the vehicle or significantly slow down its speed after impact (Table 1), thus reducing the risk of secondary collision with supports, trees, pedestrians or other road users. After hitting HE class constructions, the risk of injury to the driver is relatively greater than in the case of LE class constructions. Low energy absorbing support structures (LE) should slow down the vehicle (Table 1) to avoid further collision. The risk of injury to the driver is higher than in NE constructions, but smaller than in HE structures. Impact energy non-absorbing (NE) support structures should not stop the vehicle, but only slow it down (Table 1). When hit by a vehicle, they bring the least risk of injury to the driver and damage to the vehicle compared to the LE and HE categories.

Table 2. Vehicle occupant risk [2].

\begin{tabular}{|c|c|c|c|c|c|}
\hline \multirow{2}{*}{$\begin{array}{c}\text { Category } \\
\text { of energy } \\
\text { absorption } \\
\text { by } \\
\text { structure }\end{array}$} & \multirow{2}{*}{$\begin{array}{c}\text { Vehicle } \\
\text { occupant } \\
\text { safety } \\
\text { level }\end{array}$} & \multicolumn{2}{|c|}{$\begin{array}{l}\text { Normative impact test - speed } \\
\qquad 35 \mathrm{~km} / \mathrm{h}\end{array}$} & \multicolumn{2}{|c|}{$\begin{array}{l}\text { Speed class test }(50,70 \text { and } \\
100 \mathrm{~km} / \mathrm{h}) \text { on impact }\end{array}$} \\
\hline & & ASI & THIV, km/h & ASI & THIV, km/h \\
\hline \multirow{3}{*}{$\mathrm{HE}$} & 1 & \multirow{8}{*}{1.0} & \multirow{8}{*}{27} & 1.4 & 44 \\
\hline & 2 & & & 1.2 & 33 \\
\hline & 3 & & & 1.0 & 27 \\
\hline \multirow{3}{*}{ LE } & 1 & & & 1.4 & 44 \\
\hline & 2 & & & 1.2 & 33 \\
\hline & 3 & & & 1.0 & 27 \\
\hline \multirow{4}{*}{ NE } & 1 & & & 1.2 & 33 \\
\hline & 2 & & & 1,0 & 27 \\
\hline & 3 & 0.6 & 11 & 0,6 & 11 \\
\hline & 4 & $\begin{array}{c}\text { no } \\
\text { requirements }\end{array}$ & $\begin{array}{c}\text { no } \\
\text { requirements }\end{array}$ & $\begin{array}{l}\text { no } \\
\text { requirements }\end{array}$ & 3 \\
\hline
\end{tabular}

\section{How to use passively safe structures?}

In many European countries, work has been carried out for years on the use of passively safe road signs, lighting columns and traffic lights to reduce the risk of injury in the event of vehicles hitting such objects. Recommendations are being made regarding the selection of appropriate types of supporting structures in accordance with the requirements of EN 12767:2007, as well as additional advice for designers and organizations involved in road maintenance.

Based on the report [4], broad guidelines for designers and organizations dealing with road maintenance in the USA, Norway, Sweden, Finland, Slovakia and the United Kingdom were laid down. In the USA, it is believed that on roads with a speed limit of up to $40 \mathrm{~km} / \mathrm{h}$, vehicles provide sufficient safety to occupants inside, even in case of a collision with a stiff post or column. Stopping a moving car will be less dangerous than letting it onto the sidewalk, bicycle path or into a building. 
Among the Norwegian recommendations, it can be seen that lighting columns, signs and traffic lights structures and other supporting structures with a height below $6 \mathrm{~m}$ in the HE and LE energy absorption category should be used:

a) where it is particularly important to slow down and stop the vehicle in a controlled way, as there is a risk of it hitting dangerous obstacles, such as bridges, rock walls, etc.,

b) in built-up areas and other places where there are many pedestrians and/ or cyclists who may be injured by an uncontrolled vehicle,

c) on lanes separating roadways, so that the supporting structure is not in the way of an oncoming vehicle,

d) in areas between a road and a busy cycle path or a pedestrian path where the speed limit exceeds $60 \mathrm{~km} / \mathrm{h}$.

The Finnish recommendations clearly show that on roads where speed limit exceeds $80 \mathrm{~km} / \mathrm{h}$, it is possible to use passively safe supporting structures in the following classes HE:100:3, LE:100:3 and NE:100:2-3 (Table 2). However, on roads with a speed limit of up to $80 \mathrm{~km} / \mathrm{h}$, structures class HE:70:3, LE:70:3 and NE:70:2-3 can be used (Table 2). It is also recommended if the support structure is located between the road and a pedestrian and/or bicycle path, to use HE or LE class constructions.

The Swedish Road Administration considers road equipment to be passively safe if it meets the criteria necessary to achieve the safety level of a vehicle occupants for the selected speed class according to EN 12767. Road furnishings are considered harmless from the point of view of road safety, if the criteria for the safety level are met passengers, for speed class 50 (Table 1). These passive safety requirements apply mainly to loadbearing structures, e.g. lighting columns.

Support structures meeting the requirements for speed class 100 (Table 1) can be used on all types of roads, while structures meeting the requirements for speed class 70 (Table 1) can be used on roads with speed limits of up to $70 \mathrm{~km} / \mathrm{h}$. Support structures meeting the requirements for speed class 50 (Table 1) should not be used due to the fact that serious collisions occur in the area of speed limits of up to $50 \mathrm{~km} / \mathrm{h}$ in the case of vehicles traveling at higher speeds. It is also noted that when choosing the type of support structure, the estimated maintenance costs as well as the anticipated maintenance needs should be taken into account. In places where parking of service vehicles requires special protection, e.g. along motorways, structures with low estimated maintenance frequency should be selected.

The British recommendations were recorded in the form of the National Annex to BS EN 12767:2007. According to British recommendations, similarly to Swedish ones, support structures that meet the requirements for speed class 50 are omitted, and particular types of roads are assigned to speed classes 70 and 100, respectively (Table 3).

Table 3. Recommended speed classes according to BS EN 12767:2007 NA.

\begin{tabular}{|c|c|}
\hline Roads & Speed class $(\mathrm{km} / \mathrm{h})$ \\
\hline $\begin{array}{l}\text { Roads in undeveloped area, express roads and motorways with speed limits } \\
\qquad>40 \mathrm{mph}(\sim 65 \mathrm{~km} / \mathrm{h})\end{array}$ & 100 \\
\hline Roads in built-up area and other roads with speed limits $<40 \mathrm{mph}(\sim 65 \mathrm{~km} / \mathrm{h})$ & 70 \\
\hline
\end{tabular}

As a result, designers and organizations involved in road maintenance are required to carry out risk assessment to determine the appropriate category of energy absorption by constructions for a given type of road and location of lighting columns, road signs and traffic lights. These recommendations are summarized in Table 4, where the type of support structure has been linked to speed class, energy absorption category and passenger safety level. 
Table 4. Recommendations on the use of passively safe supporting structures according to BS EN 12767:2007 NA.

\begin{tabular}{|c|c|c|c|c|}
\hline Road & Installation site & $\begin{array}{l}\text { Lighting } \\
\text { columns }\end{array}$ & $\begin{array}{l}\text { Supporting } \\
\text { structures for } \\
\text { road signs and } \\
\text { traffic lights }\end{array}$ & $\begin{array}{c}\text { Safe } \\
\text { supporting } \\
\text { constructions }\end{array}$ \\
\hline \multirow{3}{*}{$\begin{array}{c}\text { Roads in } \\
\text { undeveloped area, } \\
\text { highways and } \\
\text { motorways with } \\
\text { speed limits } \\
>40 \mathrm{mph} \\
(\sim 65 \mathrm{~km} / \mathrm{h})\end{array}$} & $\begin{array}{l}\text { First of all, in vertical } \\
\text { clearance of motorways, } \\
\text { express roads and roads } \\
\text { with unseparated lanes }\end{array}$ & $100 \mathrm{NE} 1$ do 3 & $100 \mathrm{NE} 1$ do 3 & $100 \mathrm{NE} 4$ \\
\hline & $\begin{array}{c}\text { Places with a large } \\
\text { number of non-motorized } \\
\text { users }\end{array}$ & $\begin{array}{l}100 \mathrm{LE} 1 \text { do } 3 \\
\text { or } \\
100 \mathrm{HE} 1 \text { do } 3\end{array}$ & $100 \mathrm{LE} 1$ do 3 & $100 \mathrm{NE} 4$ \\
\hline & $\begin{array}{l}\text { In the case of a greater } \\
\text { risk related to objects } \\
\text { falling onto other roads }\end{array}$ & $\begin{array}{l}100 \mathrm{LE} 1 \text { do } 3 \\
\text { or } \\
100 \text { HE } 1 \text { do } 3\end{array}$ & $100 \mathrm{LE} 1$ do 3 & $\begin{array}{l}100 \mathrm{NE} 4 \\
\text { or } \\
70 \mathrm{NE} 4\end{array}$ \\
\hline $\begin{array}{l}\text { Roads in built-up } \\
\text { area and other } \\
\text { roads with speed } \\
\text { limit }<40 \mathrm{mph} \\
(\sim 65 \mathrm{~km} / \mathrm{h})\end{array}$ & All places & $\begin{array}{l}70 \text { LE } 1 \text { do } 3 \\
\text { or } \\
70 \text { HE } 1 \text { do } 3\end{array}$ & 70 LE 1 do 3 & $\begin{array}{l}100 \mathrm{NE} 4 \\
\text { or } \\
70 \mathrm{NE} 4\end{array}$ \\
\hline
\end{tabular}

In June 2013, the Department of Road Transport and Roads of the Ministry of Transport, Construction and Regional Development of the Slovak Republic addressed the issue of passive safety of support structures for road furnishings [5]. As a result of the work, the technical conditions TP 074 were drawn up entitled Passive safety of support structures of road equipment, which have been in force in the Ministry of Transport, Construction and Regional Development of the Slovak Republic since December 2013. The conditions [5] are to specify the requirements for selecting appropriate types of road sign support structures or other devices placed on the roads for defining levels of passive safety for particular places, in which these constructions are put up. The recommended passive safety features, depending on the maximum speed limit on roads, are shown in Table 5.

It should be emphasized that built-in areas HE category supporting constructions are designed (Table 5), with a high degree of energy absorption. These constructions significantly limit the speed of the vehicle or stop a small vehicle after impact, and such supporting constructions do not break up. This contributes to the safety of pedestrians and cyclists in relation to the secondary impact of vehicle collisions. The supporting structure that does not meet the requirements of the required class is put under class 0 . Before such a construction, a protective barrier should be installed, except for sections of the road on which the maximum speed limit is (permanently) $60 \mathrm{~km} / \mathrm{h}$ or lower [5]. This principle, 
however, does not exclude the design of supporting structures with passive safety components on these road sections.

Table 5. Recommendations on the use of passively safe supporting structures in accordance with the technical conditions of TP 074 of the Ministry of Transport, Construction and Regional Development of the Slovak Republic [5].

\begin{tabular}{|c|c|c|c|c|}
\hline Road & Installation site & Lighting columns & $\begin{array}{c}\text { Supporting } \\
\text { structures for } \\
\text { road signs and } \\
\text { traffic lights }\end{array}$ & $\begin{array}{c}\text { Safe } \\
\text { supporting } \\
\text { constructions }\end{array}$ \\
\hline \multirow{3}{*}{$\begin{array}{c}\text { Roads in } \\
\text { undeveloped } \\
\text { area, highways } \\
\text { and motorways } \\
\text { with speed } \\
\text { limits }>70 \mathrm{~km} / \mathrm{h}\end{array}$} & $\begin{array}{c}\text { First of all, in } \\
\text { vertical clearance of } \\
\text { motorways, express } \\
\text { roads and roads with } \\
\text { unseparated lanes }\end{array}$ & $100 \mathrm{NE} 1$ to 3 & $100 \mathrm{NE} 1$ to 3 & $100 \mathrm{NE} 4$ \\
\hline & $\begin{array}{l}\text { Places with a large } \\
\text { number of } \\
\text { pedestrians or } \\
\text { cyclists when road } \\
\text { accidents occur }\end{array}$ & $100 \mathrm{HE} 1$ to 3 & $\begin{array}{l}\text { a) } 100 \mathrm{HE} 1 \text { to } 3 \\
\text { b) } 100 \mathrm{LE} 1 \text { to } 3 \\
\text { c) } 100 \mathrm{NE} 1 \text { to } 3\end{array}$ & $100 \mathrm{NE} 4$ \\
\hline & $\begin{array}{l}\text { Places with high risk } \\
\text { of structures and } \\
\text { furnishings falling } \\
\text { onto the road }\end{array}$ & $100 \mathrm{HE} 1$ to 3 & $\begin{array}{l}\text { a) } 100 \mathrm{HE} 1 \text { to } 3 \\
\text { b) } 100 \mathrm{LE} 1 \text { to } 3 \\
\text { c) } 100 \mathrm{NE} 1 \text { to } 3\end{array}$ & $\begin{array}{l}\text { a) } 100 \mathrm{NE} 4 \\
\text { b) } 70 \mathrm{NE} 4\end{array}$ \\
\hline $\begin{array}{l}\text { Roads in built- } \\
\text { up and } \\
\text { undeveloped } \\
\text { areas, with } \\
\text { speed limited to } \\
70 \mathrm{~km} / \mathrm{h}\end{array}$ & All places & $\begin{array}{l}\text { a) } 70 \mathrm{HE} 1 \text { to } 3 \\
\text { b) } 100 \mathrm{HE} 1 \text { to } 3 \\
\text { c) } 70 \mathrm{LE} 1 \text { to } 3 \\
\text { d) } 100 \mathrm{LE} 1 \text { to } 3\end{array}$ & $\begin{array}{l}\text { a) } 70 \mathrm{HE} 1 \text { to } 3 \\
\text { b) } 100 \mathrm{HE} 1 \text { to } 3 \\
\text { c) } 70 \mathrm{LE} 1 \text { to } 3 \\
\text { d) } 100 \mathrm{LE} 1 \text { to } 3 \\
\text { e) } 70 \mathrm{NE} 1 \text { to } 3 \\
\text { f) } 100 \mathrm{NE} 1 \text { to } 3\end{array}$ & $\begin{array}{l}\text { a) } 100 \mathrm{NE} 4 \\
\text { b) } 70 \mathrm{NE} 4\end{array}$ \\
\hline
\end{tabular}

Letters a), b), c) etc. correspond to the order of preferences of choice determined basing on the availability of products

At present, in Poland, the legal provisions and standards do not specify the rules for the use of secure passive supporting structures located in the road lanes. An attempt to specify passive safety requirements for lighting columns located in road lanes was undertaken in 2011 by the Research Institute for Roads and Bridges in Warsaw (Table 6). The solutions shown in Table 6 were repeated in 2017 in a document prepared for the Minister of Infrastructure and Construction [7].

Table 6. Safety requirements for lighting columns located in road lanes [5].

\begin{tabular}{|c|l|c|c|c|}
\hline No. & \multicolumn{1}{|c|}{ Road category } & $\begin{array}{c}\text { Speed } \\
\text { class } \\
(\mathrm{km} / \mathrm{h})\end{array}$ & $\begin{array}{c}\text { Energy } \\
\text { absorption } \\
\text { category }\end{array}$ & $\begin{array}{c}\text { Safety level } \\
\text { of vehicle } \\
\text { occupants }\end{array}$ \\
\hline 1 & Motorways and expressways & 100 & NE & 3 \\
\hline 2 & $\begin{array}{l}\text { Other national and provincial roads (excluding } \\
\text { No. 4) }\end{array}$ & 70 & HE, LE, NE & $1,2,3$ \\
\hline 3 & District and commune roads (excluding No. 4) & 50 & HE, LE, NE & $1,2,3$ \\
\hline 4 & $\begin{array}{l}\text { National, provincial, poviat and commune roads } \\
\text { located within built-up area with no increase in } \\
\text { permissible speed limit in the meaning of traffic } \\
\text { regulations }\end{array}$ & \multicolumn{3}{|c|}{ Class 0 } \\
\hline
\end{tabular}


The document [6] also states that from January 1, 2015, all lighting columns intended for public roads will have to meet the requirements of passive safety on vehicle impact in accordance with Table 6. Columns that do not meet these requirements can still be used on motorways and expressways as well as other national, provincial, poviat and commune roads provided that road restraint systems are used, i.e. permanent safety barriers.

\section{Summary}

The review of solutions adopted by several countries (USA, Norway, Sweden, Finland, Great Britain, Slovakia and Poland) presented in the article, in the scope of using supporting structures that minimize the impact of collision, shows that this matter is solved in various ways, as in the case of Poland, there are no settlements in this matter whatsoever. Such disregard for the problem is at least strange, especially as the National Road Safety Program 2013-2020 [1] points out that vehicle speed is a key factor affecting the likelihood of road accidents and the scale of their consequences. Studies show [1] that more than $50 \%$ of drivers exceed speed limits, and the worst situation can be observed on sections passing through small and medium towns, where over $85 \%$ of drivers exceed these limits. It is also known that the most common types of fatal accidents resulting from excessive speed are: hitting a tree or a column (43\% killed), frontal collision (18\% killed), vehicle rollover (11\% killed).

In connection with the statistics shown, it seems appropriate to consider the use of passive secure (preferably NE category) support structures for streetlights, road signs and traffic lights on almost all roads. This approach to the problem (especially to lighting columns) has been adopted (unfortunately inappropriately) in many Polish cities.

It must be clearly stated that the potential risk of secondary injuries sustained by other road users (pedestrians and cyclists) in connection with continuous vehicle movement or a falling load-bearing structure causes that constructions with HE category of energy absorption should be used for a specific installation site and a designated speed limit or NE constructions, and even class 0 constructions.

Polish solutions in the use of passively secure supporting structures on roads, based on those already developed in other countries (e.g. Great Britain or Slovakia) should urgently appear in technical or legal regulations. The simplest method seems to be an amendment to Section IV, Chapter 2, Paragraph 109 of the Ordinance of the Minister of Transport and Maritime Economy of March 2, 1999, on technical conditions that should be met by public roads and on their location [8].

\section{References}

1. National road safety program 2013-2020. National Road Safety Council, Warsaw, June 2013. Ministry of Infrastructure, Warsaw 19.04.2005 (www.mi.gov.pl)

2. PN-EN 12767:2008 Passive safety of supporting structures for road equipment. Requirements and test methods

3. J. Michałek Passive safety of lighting columns, Drogownictwo 7-8/ 2013, pp. 249-255

4. G.L.Williams, J.V. Kennedy, J.A. Carroll, R. Beesley Published Project Report PPR342: The use of passively safe signposts and lighting columns, Transport Research Laboratory, Wokingham, Berkshire, Great Britain 26.02.2009 r.

5. Technical conditions TP 074 Passive safety of support structures for road furnishings, Ministry of Transport, Construction and Regional Development of the Slovak Republic, Department of Road Transport and Roads, Bratislava, 15/12/2013 
6. Passive safety requirements for lighting columns located in road lanes. Letter IDM/NN/6096/1033/2011 of August 12, 2011. The Research Institute of Roads and Bridges in Warsaw (www.ibdim.pl)

7. Guidelines for the organization of safe pedestrian traffic. Guidelines for proper lighting of pedestrian crossings. Part I - Report on the studies and analyses carried out. Consortium composed of: Foundation for the Development of Civil Engineering, Gdańsk University of Technology and the Research Institute of Roads and Bridges, in the Partnership with the Warsaw University of Technology, Minister of Infrastructure and Construction, Gdańsk - Warsaw, December 2017

8. Announcement of the Minister of Infrastructure and Construction of 23 December 2015 regarding the publication of a uniform text of the Regulation of the Minister of Transport and Maritime Economy regarding technical conditions to be met by public roads and their location 